\title{
Opportunities and Challenges for Intensive Silviculture in Alberta, Canada
}

\author{
Bradley D. Pinno ${ }^{1, *}{ }^{\mathbb{C}}$, Kazi L. Hossain ${ }^{1}$, Ted Gooding ${ }^{2}$ and Victor J. Lieffers ${ }^{1}$ \\ 1 Department of Renewable Resources, University of Alberta, 442 Earth Sciences Building, Edmonton, \\ AB T6G 2E3, Canada; kaziliaq@ualberta.ca (K.L.H.); victor.lieffers@ualberta.ca (V.J.L.) \\ 2 FORCORP, Edmonton, AB T5V 1J7, Canada; ted.gooding@forcorp.com \\ * Correspondence: bpinno@ualberta.ca
}

Citation: Pinno, B.D.; Hossain, K.L.; Gooding, T.; Lieffers, V.J. Opportunities and Challenges for Intensive Silviculture in Alberta, Canada. Forests 2021, 12, 791. https://doi.org/10.3390/f12060791

Academic Editors: Timothy A. Martin and Michael Köhl

Received: 30 April 2021

Accepted: 11 June 2021

Published: 16 June 2021

Publisher's Note: MDPI stays neutral with regard to jurisdictional claims in published maps and institutional affiliations.

\begin{abstract}
Intensive silviculture is practiced in many parts of the world but is rare in the public forests of western Canada. Here, we make the argument that intensive silviculture could be justified in Alberta but has not been implemented due to philosophies and policy decisions by foresters from government, industry and academia. These include adherence to long rotations, management goals that are aimed at sustained total volume yield rather than economic value, limitations in the types of stands that are allowed to be regenerated and models that do not include intensive silviculture options. In Mixedwood Growth Model projections, we demonstrate the potential of intensive silviculture that includes combinations of selecting good sites and thinning to produce merchantable stands by age 50 compared to the standard rotation age of 80 with basic silviculture. There could be even more gains if forest level constraints in timber flow were removed due to the increased growth of regenerating stands. Finally, we examine the attitude and policy changes that we believe are necessary for adoption of more intensive silviculture systems on parts of Alberta's forest landbase.
\end{abstract}

Keywords: intensive silviculture; forest policy; forest management; timber supply

\section{Introduction}

Intensive silviculture has been shown to increase timber productivity from 4- to 8-fold in warm temperate climates [1,2] and up to 3-fold in cooler boreal climates such as Scandinavia and Canada [3-5]. Much of Canada is approaching the end of wild timber stocks and there is a growing need to manage some of the new growing stock at a higher level of management intensity than is currently being conducted [6,7]. Alberta is well suited for implementing intensive silviculture as it has among the most productive natural boreal forests in Canada largely due to the deep and rich soils of the interior plain with high water holding capacity and nutrient availability. In addition, foresters in Alberta have access to new tools such as LiDAR-based wet areas mapping [8], derived ecosite phase maps [9] and field studies linking soil properties to plantation productivity [10] to help in the selection of appropriate sites for intensive silviculture. Alberta also has an extensive network of permanent access roads developed by both the forest industry and the oil and gas sector, demonstrated reforestation success and a highly developed forest industry.

In terms of management systems, Alberta has a long history of managing forests under the principles of even-flow sustained yield [11,12] that has been embraced by government, industry and research foresters for the last 60 years. The public forest land of Alberta are governed by a provincial Forests Act coupled with regulations and standards that must be followed by forestry companies operating on these lands. Most of the forest lands of Alberta are also under some form of independent forest certification and while each province has its own forest laws, the public forests of Canada are unified by the six principle of sustainable forest management adopted by the Canadian Council of Forest Ministers. Harvesting is generally conducted by clearcutting with retention of mature and immature 
trees for biodiversity values. Basic reforestation usually involves site preparation, planting and subsequent competition control on lands designated for conifers; these policies have been successfully applied for at least the past two decades, with $86 \%$ of harvested areas exceeding reforestation targets [13]. The basic goal of this management is to maintain pre-harvest species composition and productivity in the range of $2-4 \mathrm{~m}^{3} /$ ha/year with rotations of 70-100 years. Overall, however, such policies seem to be a compromise of promoting and sustaining wood production in the context of integrated forest management where stands and forests are to be managed for a full suite of forest values including watersheds, biodiversity and recreation. These current management systems, however, have been developed incrementally, with the best knowledge and concerns of the times when they were established, to address problems as they were identified. The forest policies currently in place now appear to be forcing a large investment on the path towards intensive management without taking the full advantage of intensive management options, including more complete competition control, commercial thinning and tree improvement [14].

Alberta recently modernized its Forests Act which will allow updates to the regulations that govern the day-to-day actions on public forests. Zoning the land into areas of different intensities of silvicultural management [15] such as in the Triad approach [16], where part of the landscape is managed intensively and other parts are managed extensively or left as reserve areas, or the five categories of intensity of the NEBIE scheme [7], need to be available as options for managers. In addition to shortening individual stand rotation lengths, intensive silviculture could also play a significant role in: (1) sustaining timber supply in times of uncertain climate and risks from fire, insects and disease [17]; (2) sustaining a flow of second growth timber of appropriate size and quality with solid wood products having a special value in long-term sequestration of carbon [18]; and (3) sustaining the viability of a forest industry providing jobs and a tax base to forested communities and the country as a whole. Furthermore, a forest industry that is actively managing the land can slowly develop adaptation strategies for issues such as climate and other risks to the forest [17,19]; when forest industries are gone such opportunities are likely to be lost [20].

In this case study, we first examine some of the opportunities for intensive management on public lands in Alberta. Then, we identify social and policy barriers to its implementation and suggest some strategies for change. We feel that the opportunities, issues and processes identified in this paper will also have applications to intensive management on public lands in other regions of Canada and other places with public forest lands.

\section{Potential of Intensive Silviculture in Alberta}

There is strong evidence that simple forest management that promotes stocking and reduction in competition can increase yield of regenerated stands beyond that of natural origin stands, e.g., [21]. Mechanical site preparation and other treatments have also been shown to increase yield and economic value [22]. Conifer growth can be doubled by early vegetation management prior to crown closure [23] and enormous increases have been reported from other long-term studies of vegetation control in plantations [14]. Several studies demonstrate that merchantable volumes increase as a result of thinning with saw$\log$ size trees at an earlier time than in unthinned stands [24,25]. The largest increase in merchantable volume occurs in stands receiving both vegetation management and early thinning with the thinning having equal importance to herbicides [26,27].

Below, we performed several simple comparative projections of white spruce (Picea glauca) plantations in Alberta with various levels of site quality and different intensities of silvicultural management. The wood volume of the various projections were developed using the Mixedwood Growth Model (MGM) that has been calibrated and validated for Alberta conditions and allows for thinning operations [28]. For our example, the target stands (Figure 1) are pure, fully stocked white spruce stands that vary in site index (SI, height in $\mathrm{m}$ at breast height age 50) from SI 18 to SI 22 and 24 . The SI value of 22 is easily in the range of plantation performance in long-term studies of well-managed plantations in Alberta [29] and the Peace River Valley of British Columbia [30]; both of these studies show 
large shifts in growth rates (and hence, site index) under different types of silvicultural treatment. The SI 18 is an historic average site productivity for many stands in the lower foothills region of Alberta. The SI value of 24 was assumed to be achieved by planting larger stock from improved seed and followed the same management regime as the other intensive scenarios.

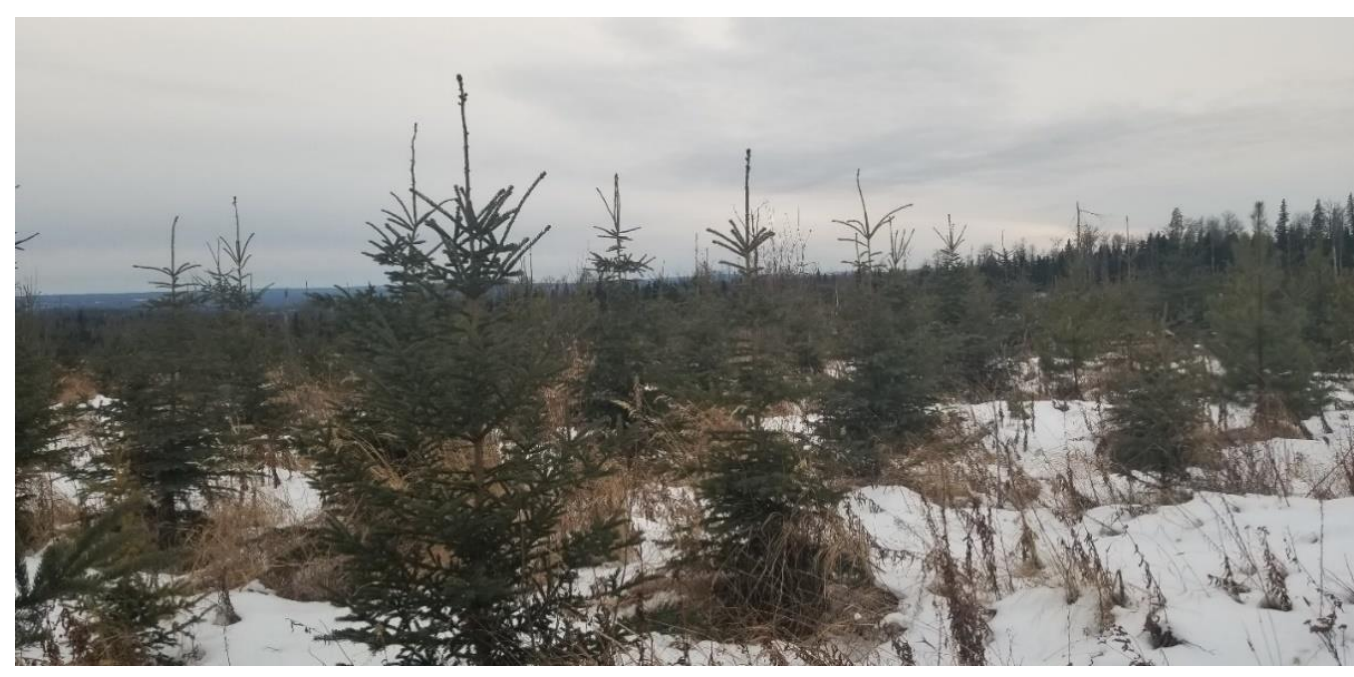

Figure 1. Example of an intensively managed, 7-year-old spruce plantation in Alberta. This stand was planted at 1800 stems per ha with improved white spruce stock, had an herbicide application at age 2, is expected to have a commercial thinning of 500 stems at age 35 and will be ready for final felling at age 50 . Photo by Brad Pinno.

In the analyses, we considered basic silviculture to be site preparation, planting to 1600 stems per ha with stock from wild seed collection, chemical competition control at year 3 , followed by growth to rotation at 80 years. In our intensive management scenarios, we initiated a similar stand but at a higher site index, planting density of 2000 stems per ha and included a commercial thinning from below at 35 years, removing $40 \%$ of basal area and merchandizing the trees reaching a sawlog size. Final felling is anticipated at year 50 . We fully acknowledge that this is a very simple assessment of intensive management and many other factors such as optimizing the starting densities, fertilization, pruning and different values for logs of different size and quality could have been applied. However, we believe that the relative impacts of intensive silviculture, site quality and rotation length on timber volume, timber value and individual tree size is informative.

At the stand level, the potential for intensive silviculture is clear, at least for some growing sites. In comparison to the standard basic silviculture scenario, intensive silviculture on average site qualities (SI 18) results in lower final volumes, MAI and individual tree sizes (Table 1). However, on better quality sites (SI 22 and 24) intensive silviculture with commercial thinning and shorter rotations results in comparable or greater MAI of merchantable volume and larger individual tree sizes relative to the basic silviculture scenario. This 30 year reduction in rotation length is likely to more than compensate for the slightly decreased final felling volumes associated with shorter rotations. 
Table 1. Volume estimates for basic and intensive silviculture scenarios of white spruce.

\begin{tabular}{|c|c|c|c|}
\hline & Volume & MAI & Tree Size \\
\hline & $\left(\mathrm{m}^{3} / \mathrm{ha}\right)$ & $\left(\mathrm{m}^{3} / \mathrm{ha} /\right.$ year $)$ & $\left(\mathrm{m}^{3} /\right.$ tree $)$ \\
\hline 1. Basic silviculture, 80 year rotation, $\mathrm{SI}=18$ & 290 & 3.6 & 0.25 \\
\hline 2. $\mathrm{CT}, 50$ year rotation, $\mathrm{SI}=18$ & 94 & 1.9 & 0.13 \\
\hline 3. $\mathrm{CT}, 50$ year rotation, $\mathrm{SI}=22$ & 179 & 3.6 & 0.25 \\
\hline 4. $\mathrm{CT}, 50$ year rotation, $\mathrm{SI}=24$ & 265 & 5.3 & 0.33 \\
\hline
\end{tabular}

Note: Scenarios 2,3 and 4 represent intensive silviculture scenarios. Volume is an estimate of merchantable volume at final felling combined with volume removed at thinning. $\mathrm{CT}=$ commercial thinning. $\mathrm{SI}=$ site index-height of top height trees at base age $50 . \mathrm{MAI}=$ mean annual increment of merchantable volume.

\section{Why Is Intensive Silviculture Not Widely Implemented in Alberta?}

The policy and regulatory structure for managing forests on public lands are put into place with the best knowledge and concerns of the times that they were established. Such regulations and standards are periodically revisited and updated with changes in knowledge and social values. The entire community of government, industry, scientists, policy analysts and people living in and using the forest should have opportunities to contribute to the updates. Below we discuss several issues (Figure 2) that need to be considered if there is an expectation of using more intensive silvicultural practices on parts of the forest landscape.

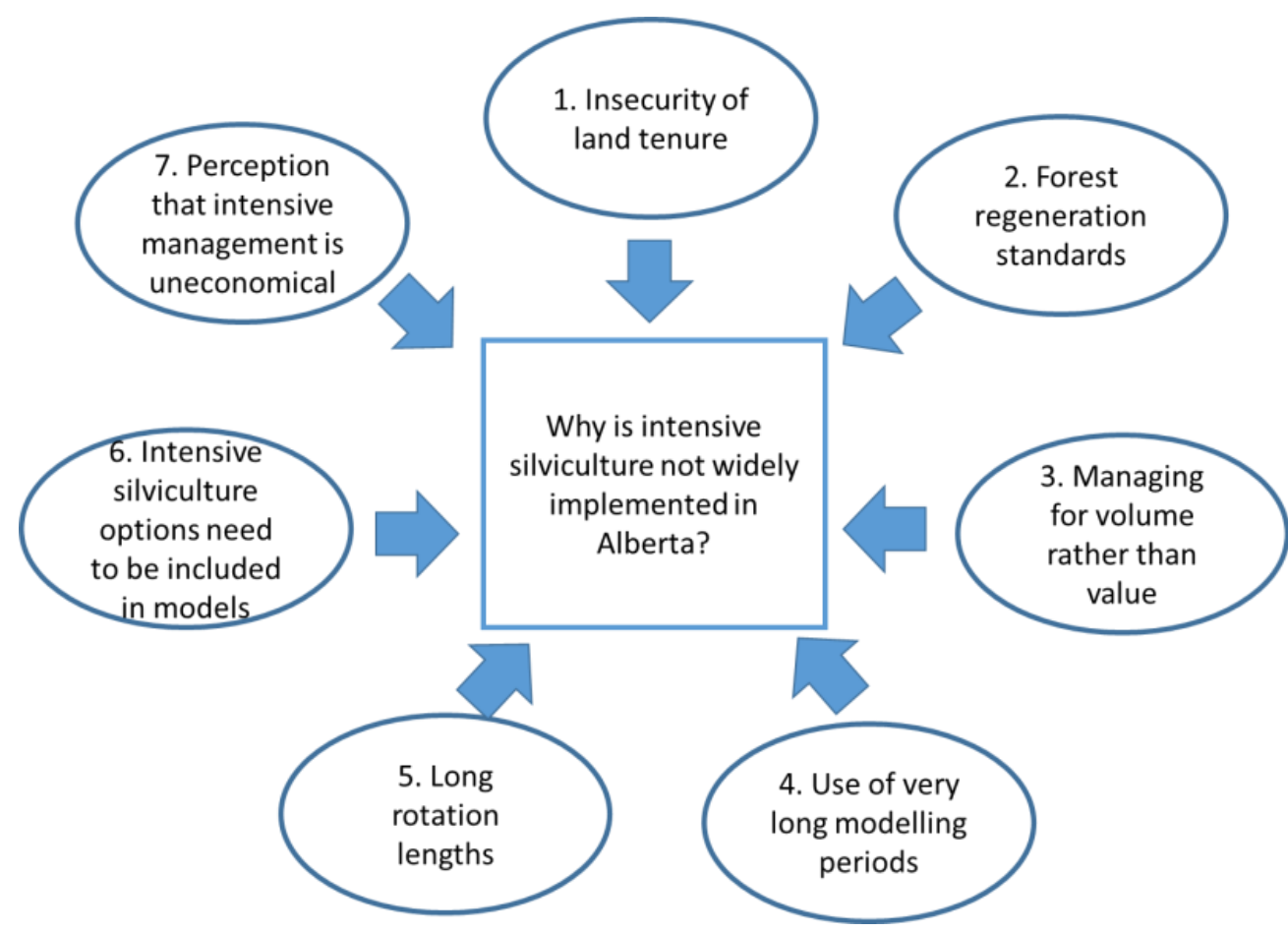

Figure 2. Factors that need updating to allow and/or promote intensive silviculture in Alberta.

\subsection{Insecurity of Land Tenure}

For private firms operating on public lands there is little reason for investment beyond basic reforestation without tenure security, especially if forest lands can be withdrawn easily for other industrial or biodiversity reasons [31]. Furthermore, Alberta has granted timber volume-based Quota agreements within the boundaries of larger area-based Forest Management Agreement (FMA) tenures to provide an annual volume of timber to other companies. This arrangement requires full co-ordination of management intensity between the FMA and Quota holders; without such co-ordination, managers would fall back toward basic silviculture and forest management. This approach is reflected in the traditional focus 
of silviculture on regeneration, associating regeneration as a cost for harvesting rather than as an investment.

Without security of tenure, the strongest incentive for industry to invest in intensive management is increases in current harvest levels through mechanisms such as the allowable cut effect (ACE) [32]. With ACE, management that accelerates growth of younger stands means that excess older stands can be cut earlier as gaps in age/size classes in the forest can be filled by earlier harvest of these intensively managed stands. Given the sustained yield system with its constraints of even-flow (see Section 3.4 below), a good value for intensive management can be achieved by the implementation of ACE. One of the goals for intensive silviculture on public land is to incent more investment in exchange for increased harvest both now and in the future while manufacturing investments are still being made.

\subsection{Forest Regeneration Standards}

Regeneration standards have been enacted to ensure sustainability of publicly owned forests [33]. These standards, negotiated between industry and government, set the minimum tree regeneration required in terms of stocking, density and species composition. More recently, Alberta has included a productivity metric with performance of regenerating stands to encourage management to meet target MAI rates [33]. Compliance with these standards is high but the density and stocking of these regenerated stands may be lower than the desired starting point for intensive silviculture activities, in particular commercial thinning. For example, planting densities of 1200-1400 stems per ha are common and may be sufficient to meet basic reforestation requirements but densities of 1800-2000 stems per ha are likely needed to allow for future commercial thinning.

The current Alberta regeneration standards are also linked to a landbase designation to maintain the current composition of deciduous, coniferous and mixedwood forests [33]. This policy restricts intensive silviculture for conifer to stands that are currently dominated by conifers, i.e., based upon late seral successional stage rather than inherent site potential. However, many of the better growing sites in the boreal might be aspen-spruce mixedwood forests which could be very productively managed as either pure deciduous, coniferous or mixed conifer forests [34]. Flexibility in this designation could allow for better overall planning of forests both for intensive management or for stands important for biodiversity conservation.

A further constraint is the requirement for using local seeds, either from wild collections or local tree improvement zones, for reforestation [35] as these may not be the most productive genotypes for future growing conditions [36]. Even further along this trajectory is potentially allowing non-native species to be planted on public land. Exotic species are not currently acceptable in Alberta on public land although in other Canadian jurisdictions some exotics have been used (example: hybrid poplar or larch in Quebec, Norway spruce in New Brunswick) and a wide variety of exotic species are planted on private land. To take full advantage of investments in intensive silviculture, the best opportunities for intensive silviculture should be promoted on a portion of the landscape. This idea is a tenet of the Triad and other forest zoning approaches that allow for increased timber production on some of the landscape in exchange for favouring other ecosystem values on other parts of the landscape.

\subsection{Managing for Volume Rather Than Value}

On public land in Alberta, sustained yield focuses on maximizing total volume derived from the forest rather than maximizing sustainable total value derived from timber production. Essentially, there is little differentiation among different timber profiles but clearly there are large differences in the value derived from stands of different configurations of timber. This approach of managing for total volume rather than value appears reasonable when high quality virgin conifer forest is being cut and simply being replaced by a stocked stand, or in forests used for pulpwood where all timber is essentially equal in value. However, 
where there is a clear premium for conifer sawtimber of the regenerated forest, 2020 average crown dues rates for large operator coniferous roundwood at $\$ 19.17 / \mathrm{m}^{3}$ compared to deciduous pulpwood at $\$ 0.47 / \mathrm{m}^{3}$ (https: / / www.alberta.ca/timber-dues-and-crown-fees.aspx; accessed on 6 January 2021), these rules do not make economic sense.

\subsection{Use of Very Long Modelling Periods}

Most forest management plans in Alberta model a timber supply that must be sustained until the last quarter of a 200-year planning horizon. This constrains average timber supply if there are gaps in the distribution of age/size classes at some time in the planning time; a common occurrence in many forests in Alberta and elsewhere (Figure 3). Intensive silviculture could accelerate growth of younger stands or derive mid-rotation timber from commercial thinning, thereby filling gaps in timber supply and leading to an increase in AAC. Shorter modelling periods have been adopted in many other parts of the world [37] to meet specific forest management objectives and call into question whether even-flow sustained yield in perpetuity is a requirement of sustainable forest management [12].

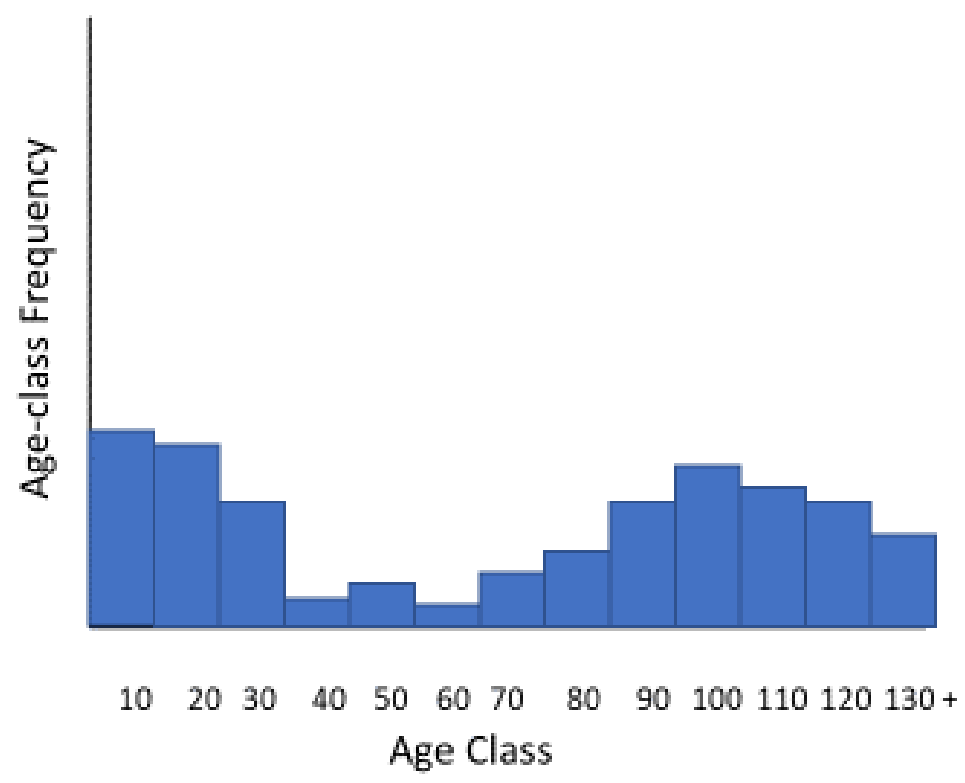

Figure 3. A hypothetical forest age class structure with excess mature stands and limited growing stock in mid-rotation stands. This type of forest is common in Alberta and would likely benefit from intensive silviculture that allows for increased harvesting of existing excess mature stands and bridges the mid-rotation timber supply gap.

\subsection{Long Rotation Lengths}

Regulators tend to restrict managers to long rotations, typically in the 70-100 year range in Alberta, for a variety of reasons. First, past approved growth models use data from wild stands that do not fully reflect the growth of managed stands. Then, at the landscape level, the scaling up of cover type strata uses the mean growth for the strata which models the poorest sites of a stratum along with the best sites. In addition, regulations in Alberta discourage thinning operations that lower final yield of a stand-'The final yield (at assumed rotation or culmination of mean annual increment) has not been compromised through planning and thinning operations' (p67 Alberta Sustainable Resource Development 2006). However, thinning may reduce total yield with the tradeoff of reduced rotation lengths and increased individual tree sizes at harvest. Delaying harvest until culmination of MAI in thinned stands will lead to the perception of no benefit of thinning operations. Finally, the biodiversity benefits of older stands may quietly push regulators to limit yield curves to longer rotations. However, if sustainable sawlog production is the goal, then intensive silviculture and thinning on some portion of the land make sense and minimum 
rotation ages should be scrapped, especially if other parts of the landscape provide older stand types for biodiversity goals.

Investments in intensive silviculture under a sustained yield umbrella will also be more attractive if ACE can be used to access merchantable timber today [32]. In many zones, past suppression of wildfire has resulted in a very old forest age structure with excess old timber (Figure 3). As a result, in many forests managers operating in a sustained yield system need to retain large tracts of mature forest in order to keep up the even-flow of timber to mills; in many circumstances these old stands might actually be declining in merchantable volume. Younger harvest ages of regenerated stands would allow more flexibility in bridging age class gaps in such forests. However, it is difficult to obtain ACE when long, fixed rotations and maximizing gross merchantable volume of a stand are a fixed goal of management.

\subsection{Intensive Silviculture Options Need to Be Included in Models}

Most western Canadian provinces have only one approved model for projecting stands forward and developing yield tables; in Alberta this model is GYPSY (Growth and Yield Projection System) [38]. From the perspective of the regulator, this is rational in that it prevents private firms from gaming with models to use the one that provides the highest yield projection. In Alberta, this one-model policy, however, limits silvicultural opportunities since in GYPSY only even-aged stands, with no intermediate harvesting such as commercial thinning, can be modelled. In addition, the GYPSY model does not yet give full recognition of the yield gain from tree improvement programs. There has been a large investment in tree improvement programs for lodgepole pine and white spruce in Alberta and results indicate substantial growth increases for improved stock but this is reflected in only a $2 \%$ growth gain relative to natural stock being granted by regulators to approved forest projections [39].

The scaling up of yield projections from the stand to the landscape scale in Alberta is also very coarse. Base-10 strata representing the main forest cover group compositions [40] broadly scale up and project average yield of these types across the landscape regardless of the site quality of the stands making up the broad type. There is the potential to also include stand origin and ecological classifications in these groupings, but in practice, this approach means that poorer sites within a stratum might be given the same silvicultural investment as the better sites, resulting in too much investment on poor quality sites and not enough on the good sites.

\subsection{Perception That Intensive Management Is Uneconomical}

In terms of productivity, there appears to be a cultural skepticism of intensive silviculture within the forestry community in Alberta. Economic analyses of intensive forestry in Alberta at the stand level support this view and have found little incentive for silvicultural investments with native species [41]; the support for higher productivity exotic species is more positive [42]. These studies, however, generally utilize natural stand growth rates with long rotation lengths, high interest rates, low lumber recovery factor at the mill and do not recognize values of residual streams of energy and pulping materials, leading to a low value of a cubic meter of wood. Further, they do not use full analysis of different timber values and costs of logging thereby inherently favouring extensive management styles. Perhaps more importantly, the use of short rotations to bridge timber supply gaps and boost AAC is a key benefit of intensive management in the framework of sustained yield management that must be evaluated at the forest rather than stand level. In the face of declining wood supplies, if intensive silviculture is not implemented the only way to increase $\mathrm{AAC}$ is to acquire existing tenures at a substantial cost.

\section{Discussion}

If intensive silviculture is to be adopted, changes are needed to our culture and regulatory system. Foresters from industry, government and academia have all contributed 
to the current state of forest management and now need to work together to change it for the better. In addition, there is a need to include land managers and scientists from disciplines outside of forestry, including those responsible for biodiversity, wildfire, social aspects and many others, in these discussions. Below, we outline some steps for implementation of intensive silviculture on public land in Alberta.

First, there must be a recognition that intensive silviculture can result in trees reaching sawlog size earlier, based on evidence from Alberta and other areas with similar climates. For example, in Nordic countries forest growth rates have increased $2-3 \times$ due to the implementation of intensive silviculture practices [3] with extreme productivity of 16-20 $\mathrm{m}^{3} / \mathrm{ha} / \mathrm{yr}$ MAI for Norway spruce in central Sweden reducing rotations lengths by 60 years [4]. Within Canada, New Brunswick has implemented intensive silviculture practices resulting in MAI of $8 \mathrm{~m}^{3} / \mathrm{ha} / \mathrm{yr}$ [5]. Early projections of growth rates in some intensively managed conifer plantation in Alberta confirms MAI of $8 \mathrm{~m}^{3} / \mathrm{ha} /$ year. Implementation of intensive management, however, must allow managers to control the type of forest that is regenerated on a particular site. This will allow the best sites, perhaps defined by soil type, access or distance to mill, to have intensive silviculture applied.

Growth and yield models must incorporate intensive silviculture. The approved model in Alberta, GYPSY, does not allow density management operations giving rise to the common sentiment that "if we can't model it, we can't grow it". Currently, the Mixedwood Growth Model allows management options such as density management but this model has not been approved by the provincial government for widespread use. Moving forward, growth and yield models should also be based in part on forward projections of growing conditions rather than relying solely on past forest growth, given the rapid progression of climate change. For this reason, there must be consideration, acceptance and use of models that are not completely validated by permanent sample plots. Furthermore, implementation of intensive management should not be penalized by requirements for additional monitoring programs that go beyond the monitoring requirements of current forest management systems. Requirements for additional and expensive monitoring programs often stall innovations; the errors associated with modelling intensive management are likely no worse than the errors in projecting the current systems.

Intensive silviculture has the potential to reduce forest level risks to drought, insects, disease, fires and other disturbances, all of which will be exacerbated by climate change. By increasing individual tree growth rates and decreasing time to stand merchantability, stands are available for harvest sooner, thereby lowering risk. These stands are also available to salvage sooner so that even if they are impacted by disturbance, value may not be completely lost. Intensive silviculture practices, such as density management and carrying stands at below maximum carrying capacity, may also reduce vulnerability to drought, fire and insect attacks $[43,44]$. These techniques are being used in both intensive silviculture and restoration forestry. For example, thinning is being used extensively to reduce fire risk and restore natural forest structure across western North America in predominantly coniferous forests with a history of frequent disturbance, e.g., [45]. Intensive silviculture could also be positioned on the landscape in locations that are less likely to be impacted by fire or other disturbances.

In conjunction with recognizing the potential yield and other benefits of intensive silviculture, there must be a simultaneous effort to demonstrate that it is not a damage to overall biodiversity at the landscape level. As discussed previously, the Triad and other zoning approaches have been suggested in some regions as they offer the potential to meet landscape management goals for biodiversity and timber by focusing on specialization of management goals for different parts of the landscape. However, the current biodiversity and non-timber value models used in the forest management planning process do not include in their analysis the full range of silvicultural options that might be applied in different parts of the forest zoned for different intensities [16]. Co-operation with wildlife managers is needed to realize the value of intensive management on part of the landscape 
while using other silvicultural strategies to produce different stand structures on other parts of the landscape.

For intensive silviculture to become an operational reality it must translate into economic gain for the forest industry in the form of AAC. This can be delivered by ACE or simply through the enhanced growth of existing stands coupled with a reduction in allowable minimum harvest ages. Most regions of the world have more flexibility in long-term plans to account for uncertainty related to climate change, disturbance risks and changes in future management priorities [37,46]. A shorter planning horizon coupled with clearer links between intensive silviculture and specific land management goals is likely needed in Alberta.

Finally, intensive silviculture demands that planning and operations foresters must have a higher level of skill than needed for traditional forestry practiced in Alberta today. For example, foresters need the skills to develop appropriate commercial thinning prescriptions for plantations including details such as intensity or amount of thinning, timing and predicting responses by site and stand characteristics. The skills of equipment operator are also critical for the success of commercial thinning operations, but most current contractors do not have the experience in this type of harvesting.

In conclusion, for intensive silviculture to become part of normal forestry operations in Alberta and likely on other public forest lands in Canada, will require changes in attitudes and policies in forest management planning. The benefits of intensive silviculture are clear, so now is the time for all those interested in public land forestry to continue the conversation related to the best way forward to meet the slate of economic, ecological and social goals that we have for our forests.

Author Contributions: Conceptualization, all authors; MGM analysis, K.L.H.; writing-original draft preparation, B.D.P. and V.J.L.; writing—review and editing, all authors; project administration, B.D.P., T.G. and V.J.L.; funding acquisition, B.D.P., T.G. and V.J.L. All authors have read and agreed to the published version of the manuscript.

Funding: This research was funded by Weyerhaeuser Company Limited and The Forest Resource Improvement Association of Alberta.

Data Availability Statement: Data available from authors upon request.

Conflicts of Interest: The funders were involved in discussions about the topic of this manuscript and provided feedback on an early draft. The funders had no role in the design of the study; in the collection, analyses, or interpretation of data; in the writing of the manuscript, or in the decision to publish the results.

\section{References}

1. Fox, T.R.; Jokela, E.J.; Allen, H.L. The development of pine plantation silviculture in the southern United States. J. For. 2007, $105,337-347$.

2. Stanturf, J.A.; Kellison, R.C.; Broerman, F.S.; Jones, S.B. Productivity of southern pine plantations: Where are we and how did we get here? J. For. 2003, 101, 26-31.

3. Senko, S.; Kurtilla, M.; Karjalainen, T. Prospects for Nordic intensive forest management solutions in the Republic of Karelia. Silva Fenn. 2018, 52, 7763. [CrossRef]

4. Bergh, J.; Linder, S.; Bergstrom, J. Potential production of Norway spruce in Sweden. For. Ecol. Manag. 2005, 204, 1-10. [CrossRef]

5. Ward, C.; Erdle, T. Evaluation of forest management strategies based on Triad zoning. For. Chron. 2015, 91, 40-51. [CrossRef]

6. Alberta Environmental Protection. The Alberta Forest Legacy. Implementation Framework for Sustainable Forest Management; Publication \#I-689; Alberta Environmental Protection: Edmonton, AB, Canada, 1998.

7. Bell, F.W.; Dacosta, J.; Newmaster, S.G.; Mallik, A.; Hunt, S.; Madhur, A.; Maloles, J.; Peng, C.; Parton, J.; McLaughlin, J.; et al. The NEBIE plot network: Highlights of long-term scientific studies. For. Chron. 2017, 93, 122-137. [CrossRef]

8. Bjelanovic, I.; Comeau, P.G.; White, B. High Resolution Site Index Prediction in Boreal Forests Using Topographic and Wet Areas Mapping Attributes. Forests 2018, 9, 113. [CrossRef]

9. Alberta Agriculture and Forestry. Derived Ecosite Phase; Version 2.0; Alberta Agriculture and Forestry: Edmonton, AB, Canada, 2020; 41p.

10. Pinno, B.D.; Thomas, B.R.; Bélanger, N. Predicting the productivity of a young hybrid poplar clone under intensive plantation management in northern Alberta, Canada using soil and site characteristics. New For. 2010, 39, 89-103. [CrossRef] 
11. Morgenstern, E.K. The origin and early application of the principle of sustainable forest management. For. Chron. 2007, 83, 485-489. [CrossRef]

12. Luckert, M.K.; Williamson, T. Should sustained yield be part of sustainable forest management? Can. J. For. Res. 2005, 35, 356-364. [CrossRef]

13. Alberta Government. Annual Status of Reforestation in Alberta Report 2016; Alberta Government: Edmonton, AB, Canada, 2017; 10p.

14. Wagner, R.G.; Little, K.M.; Richardson, B.; McNabb, K. The role of vegetation management for enhancing productivity of the world's forests. Forestry 2006, 79, 57-79. [CrossRef]

15. Binkley, C.S. Preserving nature through intensive plantation forestry: The case for forestland allocation with illustrations from British Columbia. For. Chron. 1997, 73, 553-559. [CrossRef]

16. Messier, C.; Tittler, R.; Kneeshaw, D.D.; Gélinas, N.; Paquette, A.; Berninger, K.; Rheault, H.; Meek, P.; Beaulieu, N. TRIAD zoning in Quebec: Experiences and results after 5 years. For. Chron. 2009, 85, 885-896. [CrossRef]

17. Lieffers, V.J.; Pinno, B.D.; Beverly, J.L.; Thomas, B.R.; Nock, C. Reforestation policy has constrained options for managing risks on public forests. Can. J. For. Res. 2020, 50, 855-861. [CrossRef]

18. Head, M.; Magnan, M.; Kurz, W.A.; Levasseur, A.; Beauregard, R.; Margni, M. Temporally-differentiated biogenic carbon accounting of wood building product life cycles. SN Appl. Sci. 2020, 3, 62. [CrossRef]

19. Park, A.; Wilson, E.R. Beautiful plantations: Can intensive silviculture help Canada to fulfill ecological and timber production objectives? For. Chron. 2007, 83, 825-839. [CrossRef]

20. Bennett, B.M. Plantations and Protected Areas: A Global History of Forest Management; MIT Press: Cambridge, MA, USA, 2016.

21. Huang, S.; Monserud, R.A.; Braun, T.; Lougheed, H.; Bakowsky, O. Comparing site productivity of mature fire-origin and post-harvest juvenile lodgepole pine stands in Alberta. Can. J. For. Res. 2004, 34, 1181-1191. [CrossRef]

22. Hawkins, C.B.D.; Steele, T.W.; Letchford, T. The economics of site preparation and the impacts of current forest policy: Evidence from central British Columbia. Can. J. For. Res. 2006, 36, 482-494. [CrossRef]

23. Hoepting, M.K.; Wagner, R.G.; McLaughlin, J.; Pitt, D.G. Timing and duration of herbaceous vegetation control in northern conifer plantations: 15th-year tree growth and soil nutrient effects. For. Chron. 2011, 87, 398-413. [CrossRef]

24. Pelletier, G.; Pitt, D.G. Silvicultural responses of two spruce plantations to midrotation commercial thinning in New Brunswick Can. J. For. Res. 2008, 38, 851-867. [CrossRef]

25. Das Gupta, S.; Pinno, B.D.; McCready, T. Commercial thinning effects on growth, yield and mortality in natural lodgepole pine stands in Alberta. For. Chron. 2020, 96, 111-120. [CrossRef]

26. Olson, M.G.; Wagner, R.G.; Brissette, J.C. Forty years of spruce-fir stand development following herbicide application and precommercial thinning in central Maine, USA. Can. J. For. Res. 2012, 42, 1-11. [CrossRef]

27. Bataineh, M.M.; Wagner, R.G.; Weiskittel, A.R. Long-term response of spruce-fir stands to herbicide and commercial thinning: Observed and projected growth, yield and financial returns in central Maine, USA. Can. J. For. Res. 2013, 43, 385-395. [CrossRef]

28. Bokalo, M.; Stadt, K.J.; Comeau, P.G.; Titus, S.J. The validation of the Mixedwood Growth Model (MGM) for use in forest management decision making. Forests 2013, 4, 1-27. [CrossRef]

29. Lieffers, V.J.; Sidders, D.; Keddy, T.; Solarik, K.A.; Blenis, P. A partial deciduous canopy, coupled with site preparation, produces excellent growth of planted white spruce. Can. J. For. Res. 2018, 49, 270-280. [CrossRef]

30. Powelson, R.A.; Heinemann, L.; Bedford, J.; McClarnon, A.F.L.; Nemec, L.; Boateng, J.O. White Spruce Responses to Mechanical Site Preparation, Chemical Site Preparation, and Post-Planting Vegetation Control over Three Decades in the Boreal White and Black Spruce Zone of British Columbia; Technical Report 103; Prov. B.C., Victoria, B.C.: Victoria, BC, Canada, 2016.

31. Haley, D.; Nelson, H. Has the time come to rethink Canada's Crown forest tenure systems? For. Chron. 2007, 83, 630-641. [CrossRef]

32. Hegan, R.L.; Luckert, M.K. An economic assessment of using the allowable cut effect for enhanced forest management policies: An Alberta case study. Can. J. For. Res. 2000, 30, 1591-1600. [CrossRef]

33. Alberta. Reforestation Standards of Alberta; Forest Management Branch, Government of Alberta: Edmonton, AB, Canada, 2018; 376p.

34. Lieffers, V.J.; Macmillan, R.B.; MacPherson, D.; Branter, K.; Stewart, J.D. Semi-natural and intensive silviculture systems for the boreal mixedwood forest. For. Chron. 1996, 72, 286-292. [CrossRef]

35. Alberta Agriculture and Forestry. Stream 1 and Stream 2-Alberta Forest Genetic Resource Management and Conservation Standards, Third Revision of STIA; Alberta Agriculture and Forestry: Edmonton, AB, Canada, 2016; Volume 1.

36. Sebastian-Azcona, J.; Hamann, A.; Hacke, U.G.; Rweyongeza, D. Survival, growth and cold hardiness tradeoffs in white spruce populations: Implications for assisted migration. For. Ecol. Manag. 2019, 433, 544-552. [CrossRef]

37. Franklin, J.F.; Johnson, K.N.; Johnson, D.L. Ecological Forest Management; Waveland Press Inc.: Long Grove, IL, USA, 2018; 646p.

38. Huang, S.; Meng, S.X.; Yang, Y. A Growth and Yield Projection System (GYPSY) for Natural and Post-Harvest Stands in Alberta; Technical Report Publication No. T/216; Alberta Sustainable Resource Development: Edmonton, AB, Canada, 2009; 22p.

39. Schreiber, S.G.; Thomas, B.R. Forest industry investment in tree improvement-A wise business decision or a bottomless pit? Answers from a new tree improvement valuation model for Alberta, Canada. For. Chron. 2017, 93, 38-43. [CrossRef]

40. Alberta Sustainable Resource Development. Alberta Forest Management Planning Standards; Version 4.1; Forest Management Branch: Edmonton, AB, Canada, 2006; 114p.

41. Armstrong, G.W. Considerations for boreal mixedwood silviculture: A view from the dismal science. For. Chron. 2014, 90, 44-49. [CrossRef] 
42. Anderson, J.A.; Luckert, M.K. Can hybrid poplar save industrial forestry in Canada? A financial analysis in Alberta and policy considerations. For. Chron. 2007, 83, 92-104. [CrossRef]

43. Sohn, J.A.; Saha, S.; Bauhus, J. Potential of forest thinning to mitigate drought stress: A meta-analysis. For. Ecol. Manag. 2016, 380, 261-273. [CrossRef]

44. McIntire, C.D.; Munck, I.A.; Ducey, M.J.; Asbjornsen, H. Thinning treatments reduce severity of foliar pathogens in eastern white pine. For. Ecol. Manag. 2018, 423, 106-113. [CrossRef]

45. Knapp, E.E.; Lydersen, J.M.; North, M.P.; Collins, B.M. Efficacy of variable density thinning and prescribed fire for restoring forest heterogeneity to mixed-conifer forest in the central Sierra Nevada, CA. For. Ecol. Manag. 2017, 406, 228-241. [CrossRef]

46. Puettmann, K.J.; Wilson, S.M.; Baker, S.C.; Donoso, P.J.; Drössler, L.; Amente, G.; Harvey, B.D.; Knoke, T.; Lu, Y.; Nocentini, S.; et al. Silvicultural alternatives to conventional even-aged forest management-What limits global adoption? For. Ecosyst. 2015, 2, 8. [CrossRef] 